

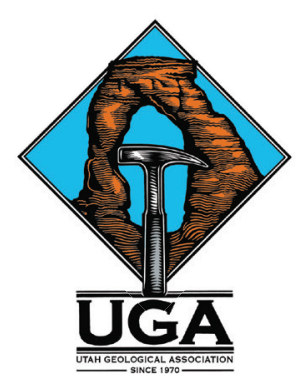

\section{Utah Geosites} 2019

\section{Utah Geological Association Publication 48}

M. Milligan, R.F. Biek, P. Inkenbrandt, and P. Nielsen, editors

Utah Geosites showcases some of Utah's spectacular geology, both little-known localities and sites seen by visitors to Utah's many national and state parks and monuments. The geosites reflect the interests of the many volunteers who wrote to share some of their favorite geologic sites. The list is eclectic and far from complete, and we hope that additional geosites will be added in the coming years. The Utah Geological Survey also maintains a list of geosites https://geology.utah.gov/apps/geosights/index.htm.

We thank the many authors for their geosite contributions, Utah Geological Association members who make annual UGA publications possible, and the American Association of Petroleum Geologists-Rocky Mountain Section Foundation for a generous grant for desktop publishing of these geosite papers.

Design and desktop publishing by Jenny Erickson, Graphic Designer, dutchiedesign.com, Salt Lake City, Utah.

This is an open-access article in which the Utah Geological Association permits unrestricted use, distribution, and reproduction of text and figures that are not noted as copyrighted, provided the original author and source are credited. See the Utah Geological Association website, www.utahgeology.org, and Creative Commons https://creativecommons.org/licenses/by/4.0/ for details.

Suggested citation for this geosite:

Atwood G., McGarry A.R., and Alderman, P.L., 2019, Ophir anticline, Tooele County - a 30-minute drive through 300 million years of bedrock, in Milligan, M., Biek, R.F., Inkenbrandt, P., and Nielsen, P., editors, Utah Geosites: Utah Geological Association Publication 48, 10 p., https://doi. org/10.31711/geosites.v1i1.46.

\section{Presidents Message}

I have had the pleasure of working with many different geologists from all around the world. As I have traveled around Utah for work and pleasure, many times I have observed vehicles parked alongside the road with many people climbing around an outcrop or walking up a trail in a canyon. Whether these people are from Utah or from another state or country, they all are quick to mention to me how wonderful our geology is here in Utah.

Utah is at the junction of several different geological provinces. We have the Basin and Range to the west and the Central Utah Hingeline and Thrust Belt down the middle. The Uinta Mountains have outcrops of some of the oldest sedimentary rock in Utah. Utah also has its share of young cinder cones and basaltic lava flows, and ancient laccoliths, stratovolcanoes, and plutonic rocks. The general public comes to Utah to experience our wonderful scenic geology throughout our state and national parks. Driving between our national and state parks is a breathtaking experience.

The "Utah Geosites" has been a great undertaking by many people. I wanted to involve as many people as we could in preparing this guidebook. We have had great response from authors that visit or work here in the state. Several authors have more than one site that they consider unique and want to share with the rest of us. I wanted to make the guidebook usable by geologists wanting to see outcrops and to the informed general public. The articles are well written and the editorial work on this guidebook has been top quality.

I would like to personally thank Mark Milligan, Bob Biek, and Paul Inkenbrandt for their editorial work on this guidebook. This guidebook could not have happened without their support. I would like to thank Jenny Erickson for doing the great desktop publishing and the many authors and reviewers that helped prepare the articles. Your work has been outstanding and will certainly showcase the many great places and geology of Utah. Last, but not least, Thank you to the American Association of Petroleum Geologists, Rocky Mountain Section Foundation for their financial support for this publication.

Guidebook 48 will hopefully be a dynamic document with the potential to add additional "geosites" in the future. I hope more authors will volunteer articles on their favorite sites. I would like to fill the map with locations so that a person or family looking at the map or articles will see a great location to read about and visit. Enjoy Guidebook 48 and enjoy the geology of Utah.

Peter J. Nielsen

2019 UGA President 


\section{INTRODUCTION}

Anticlines are not unusual features, but the Ophir anticline is exceptional. Regions shortened laterally by compressional tectonics have folds and/or faults including anticlines, synclines, monoclines, and thrust faults (figure 1). However, most anticlines are buried or partially buried, visible on land only as discontinuous snippets in road cuts or visible from above as one flies across terrain too regional to be viewed in entirety from land. The Ophir anticline is unusual as its limbs and crest can be viewed in their entirety, exposed in cross-section on Ophir Canyon's walls. Ophir Canyon provides evidence that the compressional tectonics associated with the Ophir anticline long-preceded active-extensional tectonics associated with today's basin and range topography of western Utah. This geosite is the 2 -mile $(3.2 \mathrm{~km})$ stretch of Ophir Canyon that exposes the anticline (figure 2).

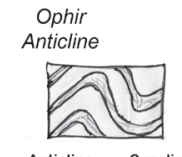

Anticline - Syncline

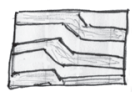

Monocline

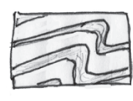

Asymetric
fold

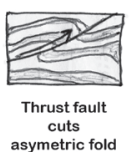

Ophir Anticline

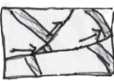

Thrust faults cut limb
of anticline.
Figure 1. Five expressions of compressional tectonics. Compression shortens portions of Earth's crust. The dips (tilts) of bedding planes define the structure of an anticline (concave upward), syncline (concave downward), and monocline (a single dipping limb). Thrust faults move older rock over younger rock.

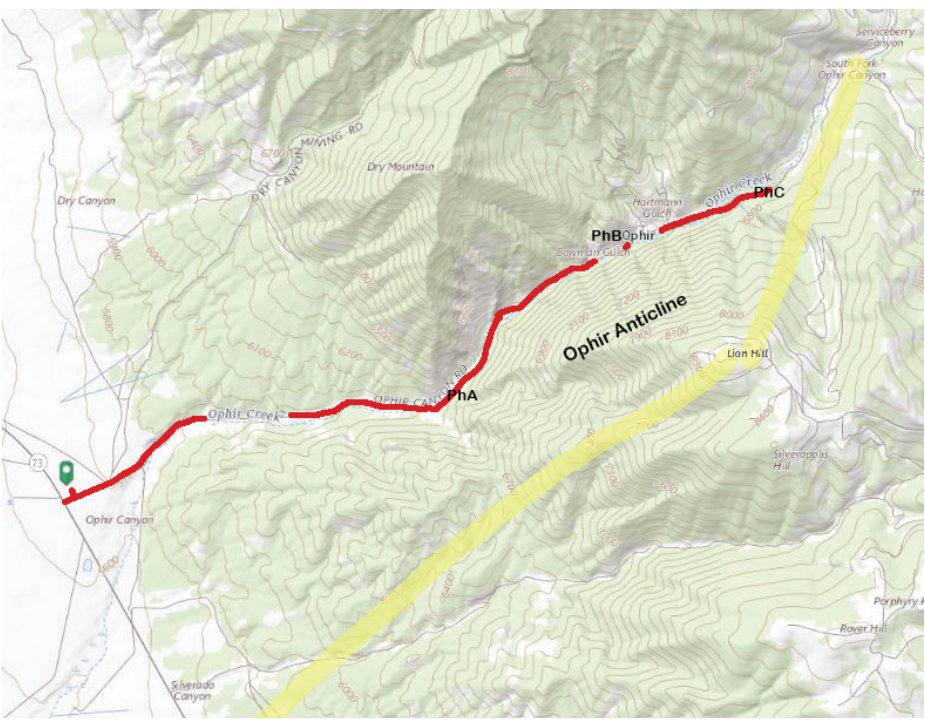

Figure 2. Location of the Ophir anticline geosite and vicinity. Base: U.S. Geological Survey, (2019).

1. Green arrow: Parking area at the intersection of Utah Road 73 and Ophir Canyon Road, GPS location, NAD83 40.35089 ${ }^{\circ} \mathrm{N} /-112.30965^{\circ} \mathrm{W}$

2. Red line: Route from parking area through the Ophir anticline to the community park and turnaround east of Ophir.

3. Ophir Anticline exposed on canyon wall.

4. PhA, PhB, and PhC indicate locations of the three photographs of figure 6 that document contrasting orientations of Ophir anticline's bedrock layers.

5. The Ophir mining district surrounds Ophir and extends into upper drainages of Ophir Creek.

6. Lion Hill directly south of Ophir is the prominent geographic feature of figure 8, the geologic cross-section of the Ophir anticline.

7. Yellow-highlighted line: General location of the geologic cross-section of figure 8 .

\section{GPS Location}

For the parking area at the intersection of State Road 73 and Ophir Canyon Road: NAD83 40.35089 N / -112.30965 W

\section{Suggested Driving Directions}

Paved roads make the geosite easily accessible (figure 3 ). From Salt Lake City, travel west on I-80, then south on Utah Route 36 through Tooele. At "Pennys Junction" south of Stockton, bear left (to the east) and continue south on Utah Route 73 to a small parking area at the intersection of Route 73 and Ophir Canyon Road.

From Utah County, travel west on Route 73 via Lehi, Cedar Fort, Fairfield, and Five Mile Pass to the small parking area at the intersection of Route 73 with Ophir Canyon Road. The intersection is well marked.

From this parking area, one can view the western range front of the Oquirrh Mountains and Ophir Canyon. The foreground terrain of alluvial fans emerging into the valley contrasts abruptly with the layered gray bedrock of the range. The parking area at $5650 \mathrm{ft}$ a.s.l. $(1720 \mathrm{~m})$ lies a few hundred feet above the Bonneville level of Lake Bonneville, the lake that occupied much of Rush Valley and most of western Utah approximately 30,000 to 13,000 years ago.

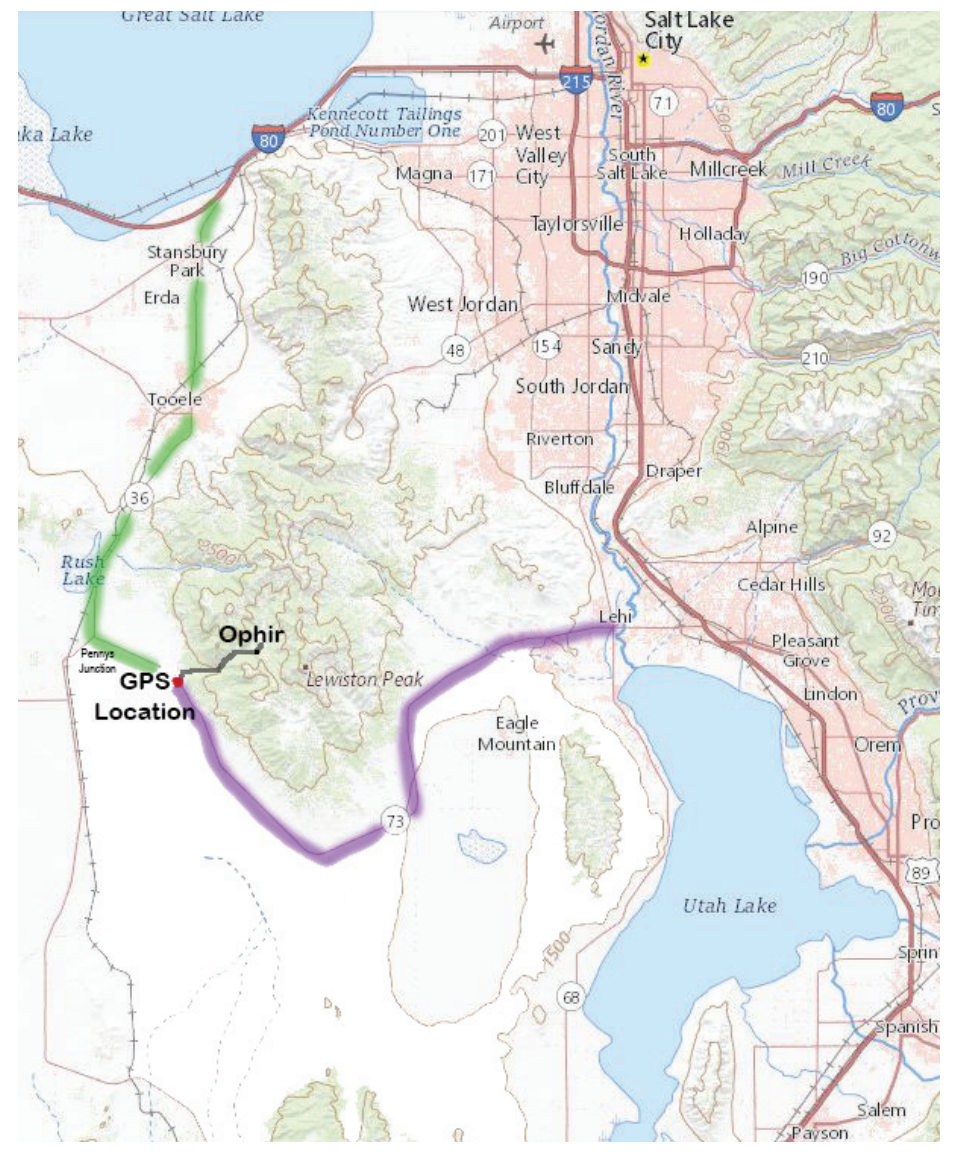

Figure 3. Location of the Ophir anticline geosite from the Wasatch Front. Base: U.S. Geological Survey (2019). Access by interstate and state highways to the geosite indicated by purple line from Utah County and by green line from I-80 west of Salt Lake County. 


\section{PHYSICAL LOCATION}

Ophir Canyon is located on the western flank of the Oquirrh Mountains, a range of the eastern Basin and Range Physiographic Province. Basins surround the Oquirrh Mountains including Rush Valley west of Ophir Canyon (figure 4).

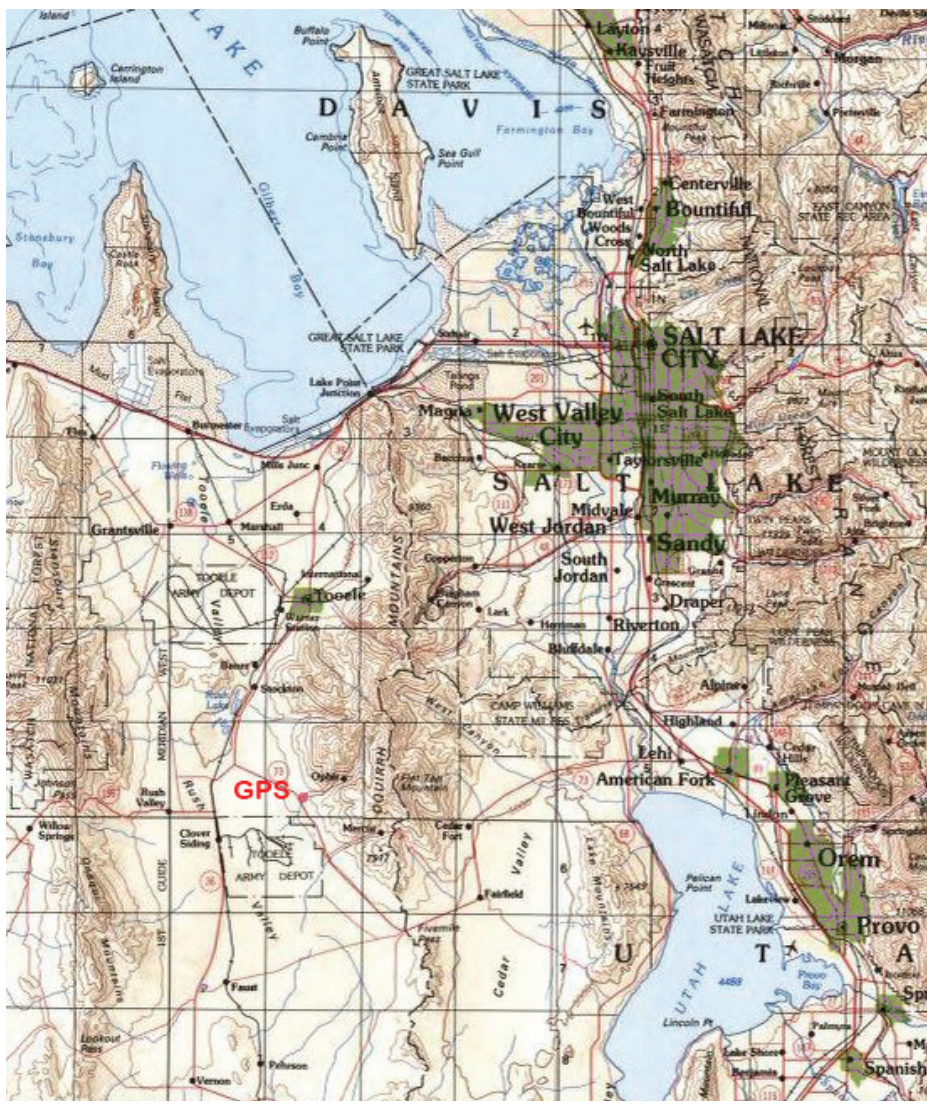

Figure 4. Physical features of the Oquirrh Mountains and environs. Base: U.S. Bureau of Land Management (1993). The red "GPS" marks the intersection of State Road 73 and Ophir Canyon Road. Olive green indicates urban development.

Ophir Canyon and the Oquirrh Mountains lie west of Utah's hingeline, the north-south trending structural zone also called the Wasatch line, and along the projection of the east-west Uinta trend or Uinta axis discussed in Stokes (1986), Hintze and Kowallis (2009), and Clark and others (2019). The Ophir anticline and mining district lie along an east-west mineral belt that continues east to Park City and west to Gold Hill (Krahulec, 2018). For over a century, geologists have worked the area and puzzled over its geologic relationships (figure 5).

\section{OPHIR ANTICLINE GEOSITE}

The drive from the parking area (intersection of Route 73 and Ophir Canyon Road) through the anticline is short with attendant hazards including rockfalls, wildlife, and driving distracted by geology. Consider traveling the route twice: once for the lay of the land, and again to pull onto the road's shoulder to take photos and recognize patterns of bedrock layering, specifically the limbs and crest of the Ophir anticline (figure 6).

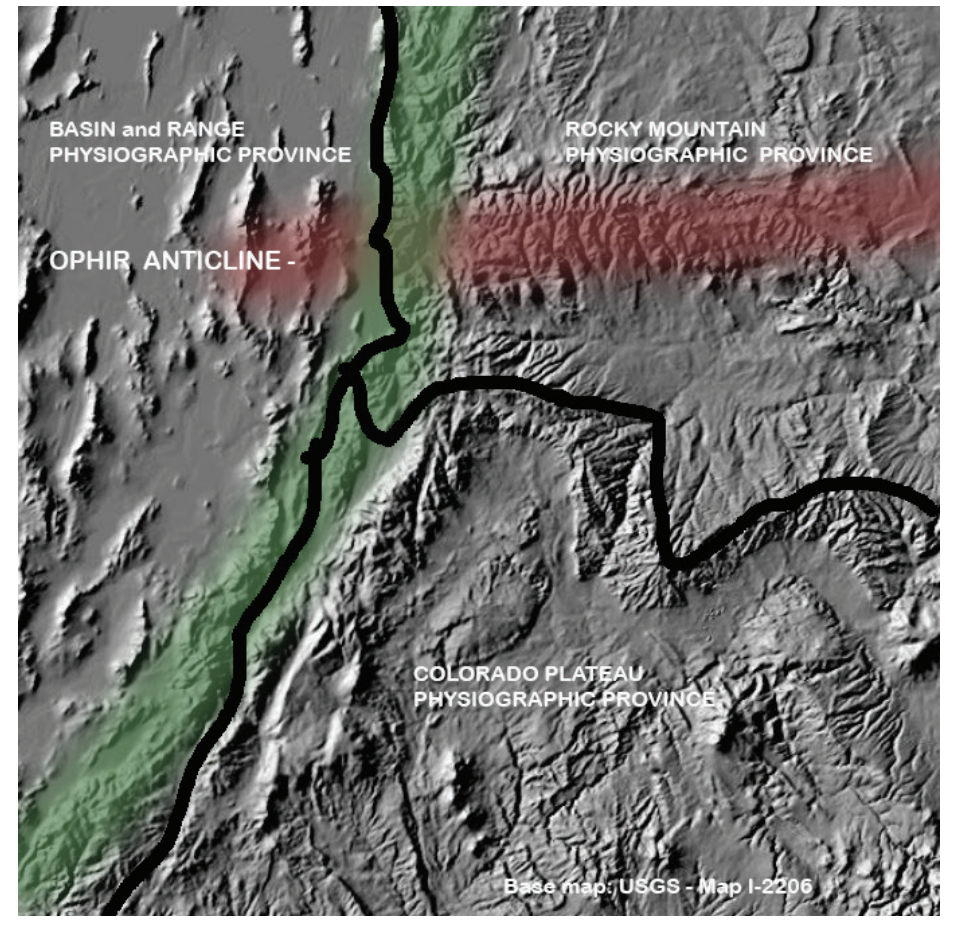

Figure 5. Geologic context of the Ophir anticline geosite. Base: Thelin and Pike (1991). Colors highlight two major structural features of Utah geology. The green band highlights the north-south trending Utah hingeline. The red band highlights the east-west Uinta trend. These structural zones have accommodated and influenced significant changes in Utah's crust (Hintze and Kowallis, 2009) and persisted through the 500 million-year bedrock history of the Oquirrh Mountains (Clark and others, 2019).

The route has three sections: (1) approximately 2 miles $(3.2 \mathrm{~km})$ across alluvial fans to the Ophir anticline, (2) approximately 1.5 miles $(2.4 \mathrm{~km})$ through the west limb of the anticline to its crest opposite the community of Ophir, and (3) approximately 0.5 mile $(0.8 \mathrm{~km})$ via a well-maintained dirt road into the east limb of the anticline. Consider parking at the turnaround at open fields beyond the community park to investigate the bedrock.

Alluvial fans and stream deposits dominate the terrain between the parking area and the geosite. Active (Holocene, within approximately the past 12,000 years) normal faults cut the alluvium between the parking area and the range front (figure 7). Kirby (2012) summarizes several hazards-related investigations that present evidence that active and older normal faults cut and define the range front (Bucknam, 1977; Everett and Kaliser, 1980; Barnhard and Dodge, 1988).

Driving east into the canyon, travelers cross abruptly into gray, layered, west-dipping bedrock of the west limb of the Ophir anticline. Following the west-dipping strata eastward results in traveling through older and older layers of bedrock until arriving at Ophir. Approaching Ophir, the tilting of bedrock layers diminishes to horizontal at the anticline's axis. A half-mile $(0.8 \mathrm{~km})$ east of Ophir, at the turnaround and fields, the rock layers dip to the east defining the eastern limb of the anticline. Patterns of bedrock orientation are shown in photographs (figure 6) and in geologic 
West limb of the anticline. Looking north. Note Peg Alderman (lowest center) for scale and representation of westward tilt of bedrock.

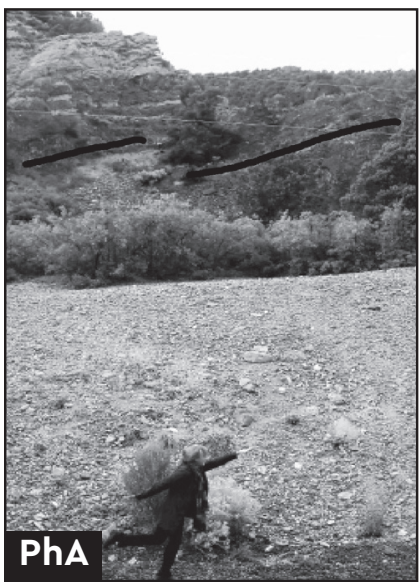

Crest of the anticline. Ophir, looking south. Genevieve Atwood for scale and representation of the nearly horizontal layering of the bedrock.

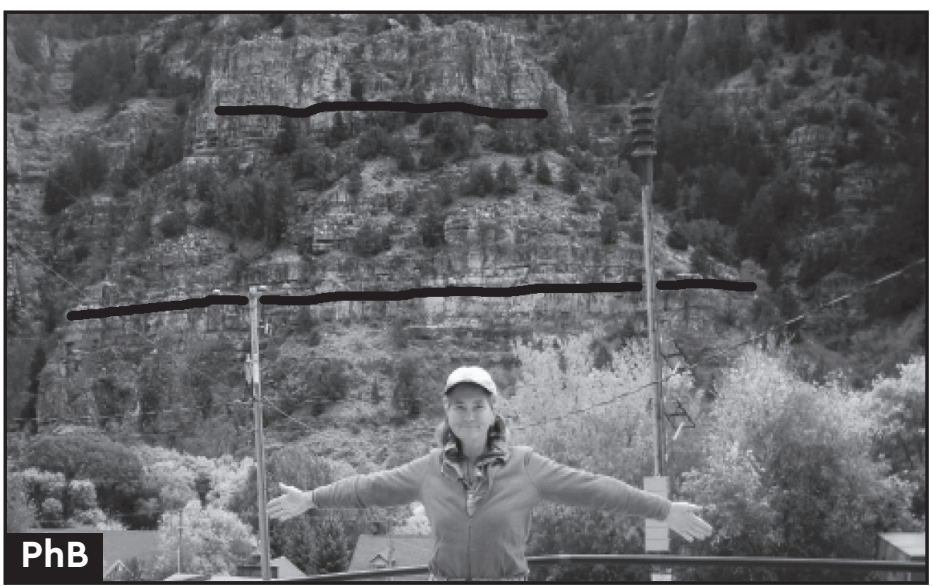

East limb of the anticline. Looking north from the park east of Ophir. Peg Alderman for scale and representation of eastward tilt of the bedrock.

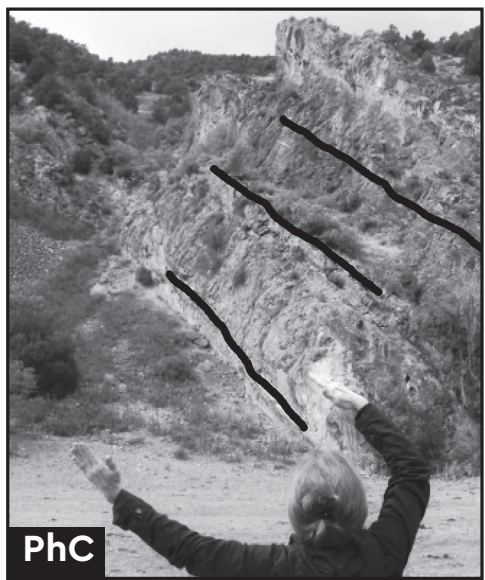

Figure 6. Contrasting orientations of Ophir anticline's bedrock layers. Modified from Atwood (2018). Three photographs show contrasting patterns of bedrock layering in Ophir Canyon. The patterns define the essential structure of an anticline. At PhA (see figure 2 for location) the west limb of the Ophir anticline, the layers dip west, meaning, trend downward toward the west. A black line highlights the trend to contrast bedrock surfaces from utility lines. At PhB, along the crest of the anticline on the face of Lion Hill, the bedrock layers' orientation is nearly horizontal. At PhC, east of Ophir, the layers dip to the east. The canyon exposes bedrock almost continuously providing multiple places to examine layers and appreciate their structure.

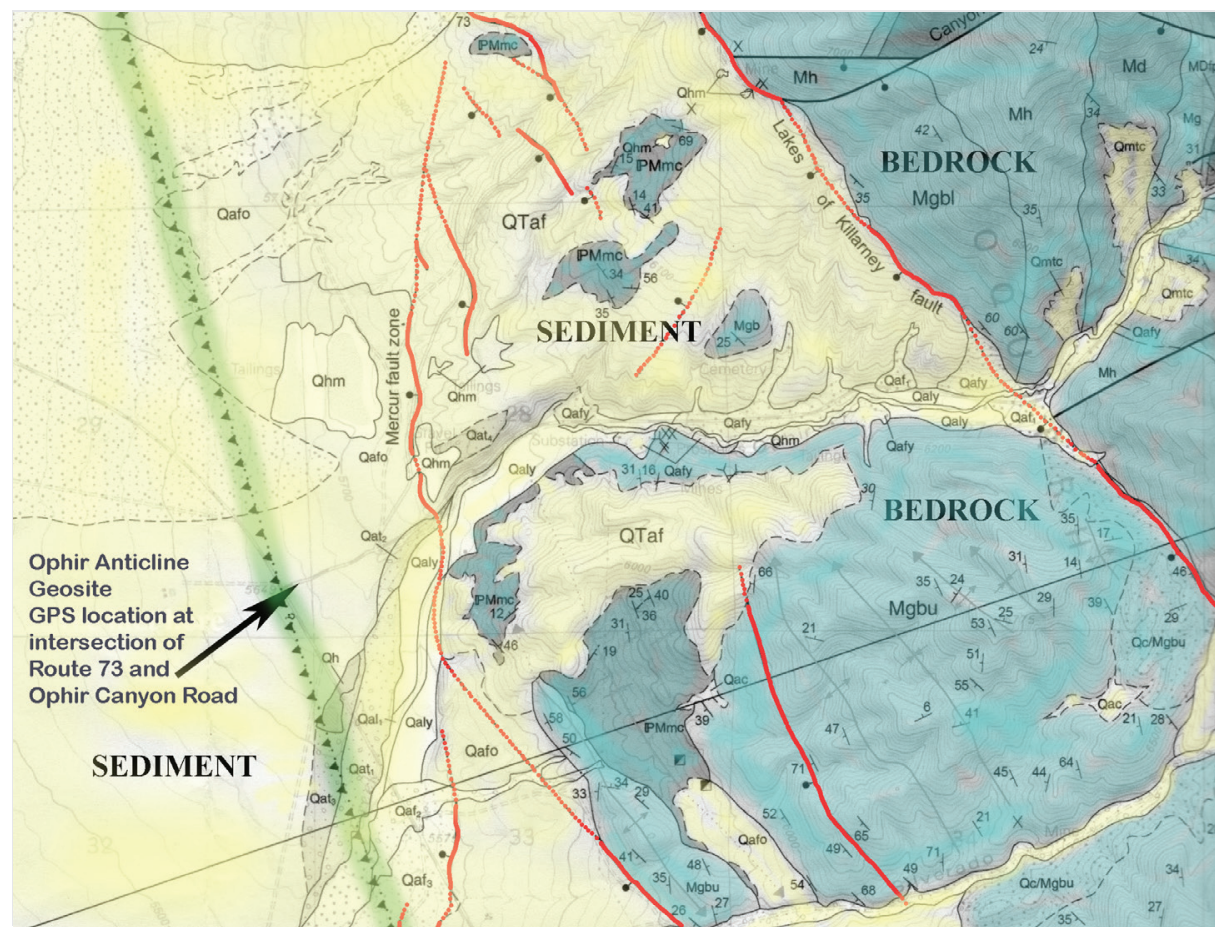

Figure 7. Geologic map of features west of the Ophir anticline geosite. Base: Kirby (2012). The parking area at the GPS location provides a view of relationships of bedrock (blue) versus sediments (yellow). Patterns of layered bedrock exposed on hillslopes indicate post-depositional tilting by compressional tectonics. Red lines mark mapped range-front extensional faults. The green hachured line marks the general trend of a compressional fault now buried by far-younger sediment. Young (red) faults cut valley-fill sediments as well as bedrock. Therefore they are younger than those units. These range-front faults cut the folded bedrock of the Ophir anticline at the mouth of the canyon. Therefore, range-front faulting is far younger than the compressional tectonics that folded bedrock into the Ophir anticline. 


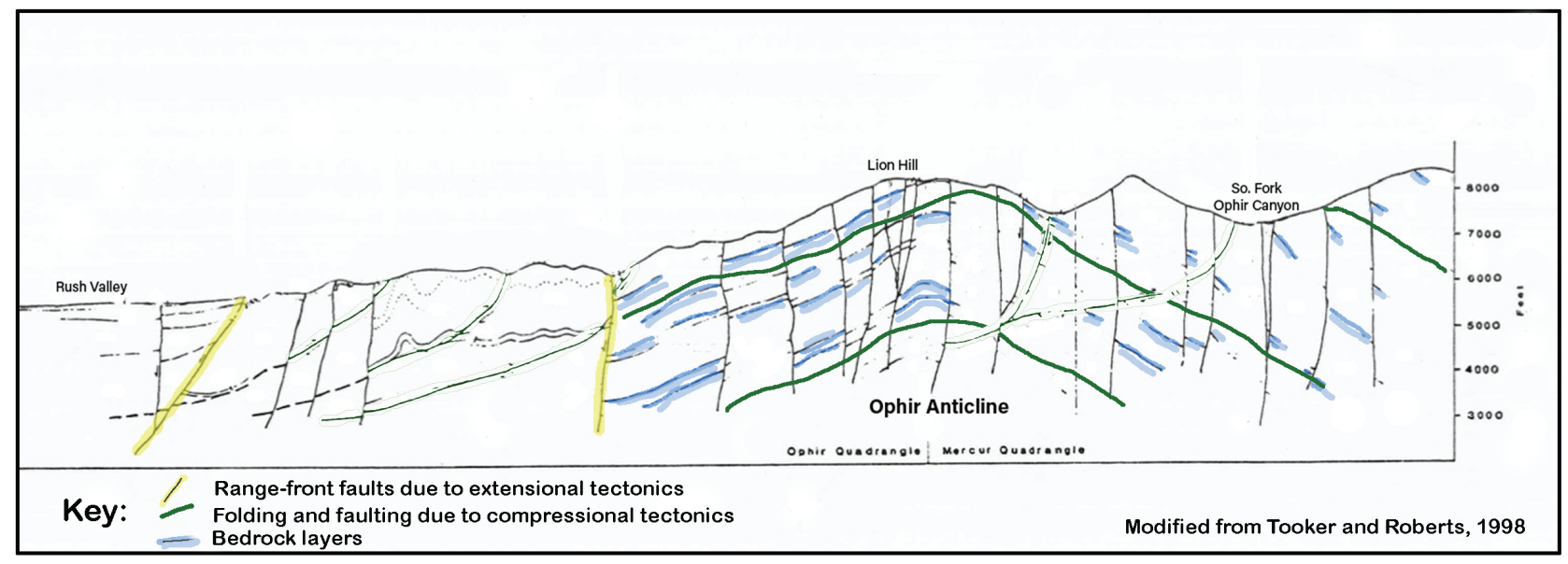

Figure 8. Geologic cross-section of the Ophir anticline. Base: Tooker and Roberts (1998). This cross-section has been modified substantially from Tooker and Roberts (1998) to emphasize the general structure of the Ophir anticline. The figure does not show Tooker and Robert's labels for the age of stratigraphic units. The figure deemphasizes their interpretation of thrust faults (interpretations not shared by Clark and others, 2019). Tooker and Robert's interpretation is shown faintly in green. What is shown, highlighted in blue are bedrock layers. Their general orientation defines the Ophir anticline. The yellow-highlighted lines represent younger, normal faults. These range-front faults cut the anticline and form the boundary between Rush Valley and the Oquirrh Mountains. The colors of the cross-section tie to figure 10 - Geologic history of Ophir and vicinity. Blue lines represent bedrock of Chapter 3 - Shallow Seas and Chapter 4 - Broad Basins. Green lines represent effects of compressional tectonics during Chapters 6 - Scrunch and Chapter 7 - Seven Up that folded the bedrock layers into the Ophir anticline. Yellow lines represent faults and bedrock displacement due to extensional tectonics of Chapter 9 - Now, Stretching to the west.

cross-section (figure 8). The cross-section's blue-highlighted layering conveys the anticline's simple form. The numerous faults that displace generally-gray dipping bedrock layers against generally-gray dipping layers makes correlation of rock units challenging.

Ophir Canyon provides a window into the mountain range. Near Ophir it exposes Cambrian limestone, the oldest bedrock exposed in the Oquirrh Mountains (Parry, 2016). The two geologic maps of figure 9 present the coarse-scale generalized message of the anticline and the finer-scale detailed geology important for exploration geologists. Both maps show the anticline's structure and raise intriguing questions, such as, why the rock record is missing between the significantly younger bedrock of the anticline (M=Mississippian) and the older bedrock ( $\mathrm{C}=$ Cambrian) that cores the anticline.

\section{OPHIR, HISTORIC MINING TOWN AND MINING DISTRICT}

The community of Ophir takes pride in its mining heritage. The historic district, marked by a flagpole at the town's center, includes original buildings and historical markers. The old schoolhouse, notable for its history, has spectacular views south to Lion Hill and the eroded crest of the Ophir anticline (central photograph of figure 6). Evidence of the district's mining operations include adits, tunnels, waste rock, and rail grades.

The numerous mining districts of the Oquirrh Mountains, including the Bingham ore deposits and those of Ophir, have produced remarkable riches. According to W.L. Stokes, "The Oquirrh Mountains are good contenders for the title of 'richest mountains on Earth"' (1986, p. 171). According to Utah Mining Districts,

(Krahulec, 2018, p. 119):
The Ophir District is about the tenth most productive in Utah. Ophir is credited with production of about 2.8 million tons of ore averaging $6.2 \% \mathrm{~Pb}, 1.5 \% \mathrm{Zn}, 0.8 \% \mathrm{Cu}, 237 \mathrm{ppm} \mathrm{Ag}$, and $0.21 \mathrm{ppm} \mathrm{Au}$, recovered. Total district metal production at modern metal prices is estimated at $\$ 877$ million. The Ophir Hill mine in Ophir Canyon is the largest producer in the district with about 1.5 million tons of production followed by Hidden Treasure mine at 300,000 tons (Rubright, 1978).

Explanation of the unusual structures and ore deposits of the Ophir mining district (Krahulec, 2018; Parry, 2004) is beyond the scope of this paper. However, the Ophir anticline, its structure, and associated fracturing of the bedrock favored later mineralization associated with igneous intrusions and fluid interactions (Kirby, 2012). The mining district aligns with the crest of the anticline. The layered nature of the district's ore prompted innovative mining methods and impressive legal implications lasting to the present (Parry, 2004).

Processes associated with igneous activity deposited ore in the bedrock of the Ophir anticline. The presence of the anticline and associated faulting may have influenced mineralization, but mineralization of the Ophir district did not influence the formation of the anticline.

\section{STRUCTURE, STRATIGRAPHY, AND GEOLOGIC HISTORY}

The Ophir anticline has intrigued geologists for over a century (Butler and others, 1920; Gilluly, 1932; Laes and others, 1997; Tooker and Roberts, 1998; Handwerger and others, 1999; Kirby, 2012; Clark and others, 2012; Clark and others, 2019). Novice and 


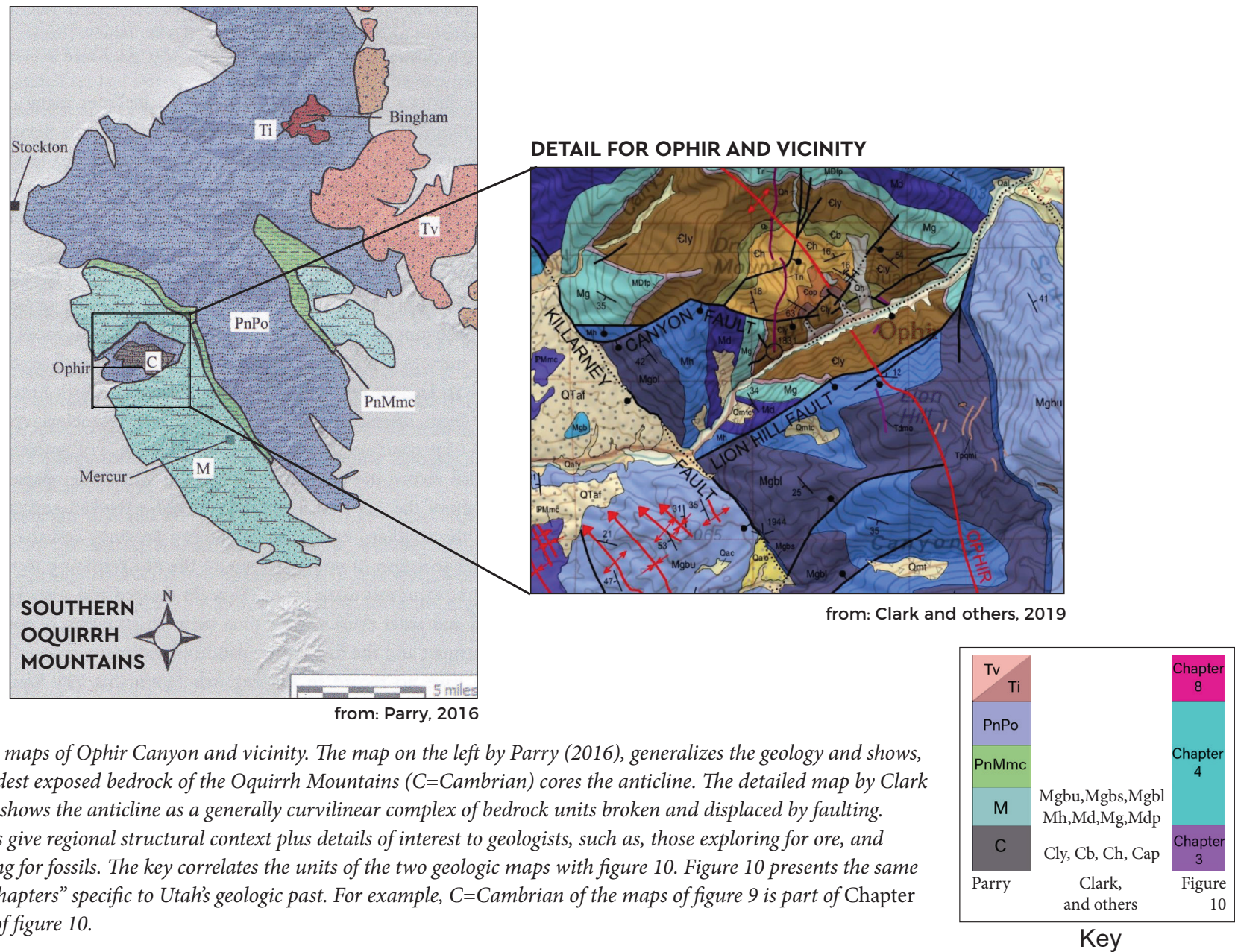

Figure 9. Geologic maps of Ophir Canyon and vicinity. The map on the left by Parry (2016), generalizes the geology and shows, simply, how the oldest exposed bedrock of the Oquirrh Mountains (C=Cambrian) cores the anticline. The detailed map by Clark and others (2019) shows the anticline as a generally curvilinear complex of bedrock units broken and displaced by faulting. Together, the maps give regional structural context plus details of interest to geologists, such as, those exploring for ore, and rockhounds hunting for fossils. The key correlates the units of the two geologic maps with figure 10. Figure 10 presents the same history but uses "chapters" specific to Utah's geologic past. For example, C=Cambrian of the maps of figure 9 is part of Chapter 3 - Shallow Seas of figure 10.

\section{Age Relationships}

expert geologists alike can enjoy the puzzle of structure, bedrock units, and present landforms. Specifically, the Ophir anticline contradicts a misconception that the mountain building that caused the Ophir anticline and similar folded bedrock of western Utah is the mountain building of today's basin and range topography. The compressional tectonics that formed the Ophir anticline predates the extensional tectonics of today's basins and ranges by over 100 million years.

The geosite's geologic history can be told as chapters using terminology of Hintze (2005) and Hintze and Kowallis (2009). That history is summarized in figure 10. Working backwards through time, the chart summarizes how extensional tectonics of Chapter 9 - Now! creates the feature, the Oquirrh Mountains. Mineralization associated with tectonics of Chapter 8 - Impressive Igneous deposited ores of the Ophir District and Oquirrh Mountains. Uplift due to tectonic forces of Chapter 7 - Seven Up! raised the region high. Compressional-tectonic forces of Chapter 6 -Scrunch... created the Ophir anticline thousands of feet below the land surface. Relatively quiescent tectonic forces of Chapter 4 - Broad Basins and Chapter 3 - Shallow Seas created environments where sediments accumulated and became thousands of feet of layered-gray bedrock of today's western Oquirrh Mountains.
Superposition of layers of bedrock and cross-cutting relationships of folding and faulting are the evidence for interpreting the geologic history of the Ophir anticline geosite. Retelling that history from oldest to youngest may reinforce recognition of age relationships observable in Ophir Canyon. Specifically, the compressional tectonics that created the Ophir anticline preceded present-day extensional tectonics by millions of years. Figure 10 summarizes the geologic history of Ophir Utah three ways: as millions of years, as traditional breaks of time with traditional geologic names, and as chapters of Utah's geologic history. Figure 11 tells the sequence in sketches. The sketches illustrate critical stages of development of the Ophir anticline geosite:

(1) Processes of sedimentation and lithification formed the bedrock for the anticline during Chapter 3 - Shallow Seas and Chapter 4 - Broad Basins.

(2) Compressional tectonics folded and uplifted the anticline during Chapter Six - Scrunch and Chapter Seven - Seven Up!

(3) Extensional tectonics created the topographic relief for Ophir Canyon and exposure of the anticline during Chapter Nine Now! Extensional tectonics westward. 
Geologic History of Ophir, Utah and vicinity.

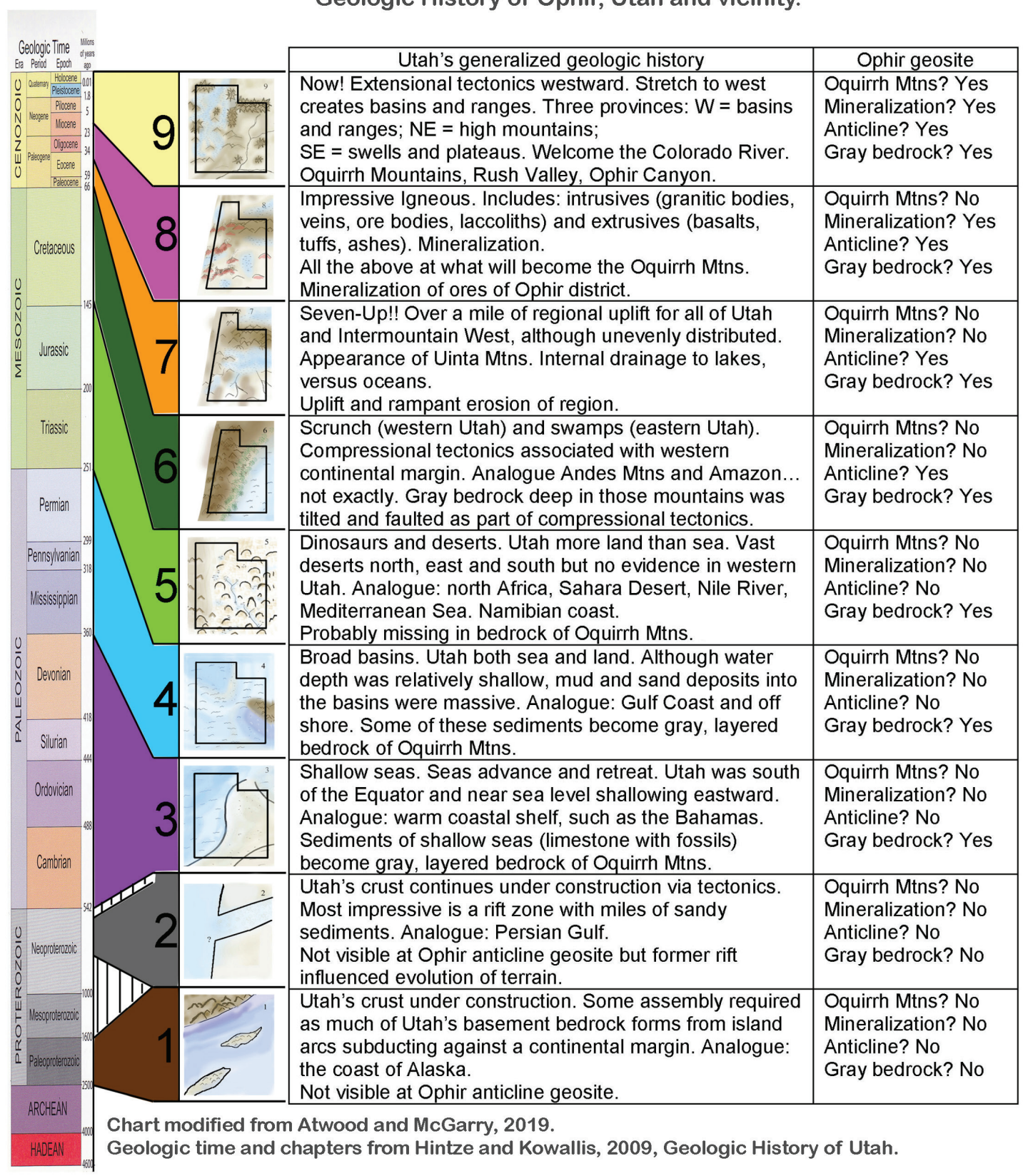

Figure 10. Geologic history of Ophir, Utah and vicinity. Modified from Atwood and McGarry (2019). Chapter terminology from Hintze (2005) and Hintze and Kowallis (2009).

The following discussion addresses the misconception that the compressional folding of the Ophir anticline also created today's Oquirrh Mountains, a classic range of basin and range topography. This summary draws on Hintze and Kowallis (2009).

Bedrock of the Ophir anticline: The gray bedrock of Cambrian, Mississippian, and Pennsylvanian age (shown in photographs of figure 6 and in maps of figure 9), began as muddy sediments laid down in shallow seas. Shallow-marine fossils encased in what was once limy muds indicate that Utah then was below sea level and near the equator (Hintze, 2005; Hintze and Kowallis, 2009). Continued deposition resulted in thousands of feet of sedimentary bedrock layers.
Folding the Ophir anticline: Over 100 million years after the bedrock was buried, compressional tectonics during Cretaceous and early Tertiary time shortened and uplifted Utah's crust. In response to this mountain building of the Sevier and Laramide orogenies, Tooele County's topography resembled mountain ranges as high as today's Andes Mountains. At depth, within the mountains' roots, folding and faulting created compressional features including the Ophir anticline.

Did the compressional tectonic forces that made those mountains and the Ophir anticline create today's Oquirrh Mountains? The evidence can be unraveled by cross-cutting relationships illustrated in figure 8 - Geologic cross-section of Ophir anticline and in figure 9 - Geologic maps of Ophir Canyon and vicinity. Igneous intru- 


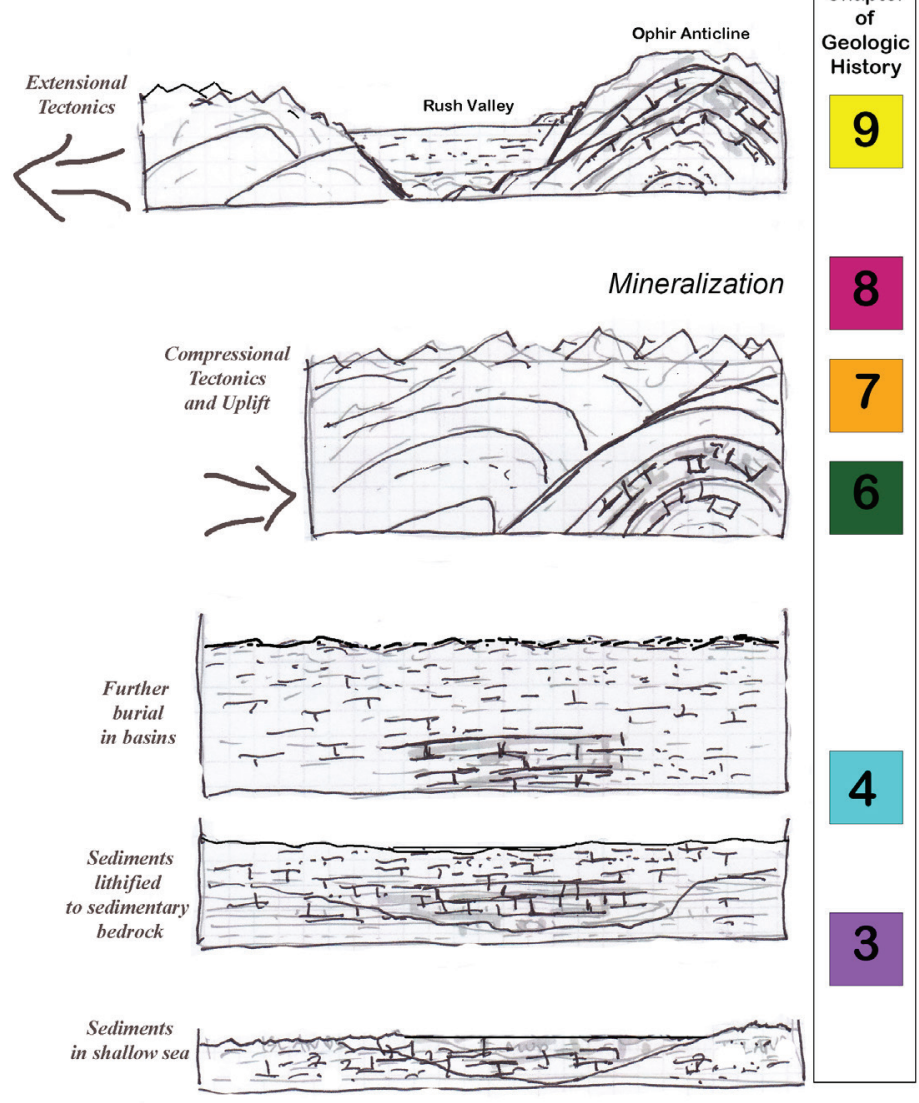

Figure 11. Critical stages of development of the Ophir anticline geosite. Modified from Atwood (2018). Numbers tie to chapters of Utah's geologic past presented in figure 10. Tectonics rules! Geology is cumulative. Our present understanding of the architecture of western Utah's crust includes how ancient zones of weakness remobilize during subsequent chapters of tectonics. The ore of the Ophir mining district was affected by the anticline although the compressional forces that folded it into the anticline long-preceded the processes that resulted in mineralization. Similarly, the compressional forces that caused the folding of the anticline long-preceded the extensional forces that resulted in basin and range topography including the Oquirrh Mountains and Rush Valley.

sions cut the folded bedrock of the Ophir anticline about 36 my ago (Kirby, 2012) dating the approximate age of mineralization of the Ophir anticline. Ophir Canyon cuts through mineralized rock layers of the Ophir anticline. Therefore, the canyon is younger than the intrusions, the mineralization, the compressional tectonics of the anticline, and the bedrock units of the anticline. Ophir Creek cuts Ophir Canyon, meaning the creek cuts deep into the Oquirrh Mountains. Streams require topography. Ophir Creek flows from high terrain to lower terrain, from a range to a basin. Basin and range topography necessarily preceded and has evolved with the canyon.

The mountains that existed in response to the compressional tectonics that folded the Ophir anticline are long gone. Range-front faults located at the mouth of Ophir Canyon cut modern alluvial fans showing that active extensional processes continue to drop the valleys with respect to the mountains (figure 7). Extensional forces continue to create the Oquirrh Mountains, a range of the Basin and Range Physiographic Province. The Ophir anticline existed before basin and range topography. The compressional tectonic forces that bent buried bedrock into the Ophir anticline did not create today's landform, the Oquirrh Mountains.

This brief history omits discussion of several intriguing questions pertaining to Ophir Canyon, the Ophir mining district, and the Oquirrh Mountains. Why are entire sections of geologic time unrepresented in the rock record? Why does the layered structure of ore bodies of the Ophir mining district differ from others of the Oquirrh Mountains? Why are the Oquirrh Mountains exceptionally mineralized?

\section{WHAT MAKES THIS GEOSITE WORTH A VISIT?}

The relationships of the Ophir anticline, its bedrock layers, and how Ophir Creek exposes the anticline in Ophir Canyon are all visible from Ophir Canyon Road. When one comprehends the relative ages of Ophir Canyon's bedrock, the bedrock's mineralization, and today's topography all with respect to the anticline, one can appreciate the generalized geologic history of many ranges of the Basin and Range Physiographic Province.

\section{ACKNOWLEDGMENTS}

The authors are grateful to Tooele School District for sponsoring Earth Science Education's Earth Science Outside field experiences in Ophir Canyon. John A. Canner and Tamara J. Wambeam assisted with maps. This paper has benefited greatly from informal and formal reviews by William T. Parry and Donald L. Clark.

\section{REFERENCES}

Atwood, G., 2018, Ophir Canyon - tectonics past and present for Tooele School District teachers: www.earthscienceeducation. org/ accessed January and February 2019.

Atwood, G., and McGarry, A.R., 2019, Geologic history of a Utah place - generic chart: www.earthscienceeducation.org/ geologic-history-of-utah-for-teachers/ accessed January and February 2019.

Barnhard, T.P., and Dodge, R.L., 1988, Map of fault scarps formed in unconsolidated sediments, Tooele $1^{\circ} \times 2^{\circ}$ quadrangle, northwestern Utah: U.S. Geological Survey Miscellaneous Field Studies Map MF-1990, scale 1:250,000.

Bucknam, R.C., 1977, Map of suspected fault scarps in unconsolidated deposits, Tooele $2^{\circ}$ sheet, Utah: U.S. Geological Survey Open-File Report 77-495, scale 1:250,000.

Butler, B.S., Loughlin, G.F., Heikes, V.C., and others, 1920, The ore deposits of Utah: U.S. Geological Survey Professional Paper 111, 672 p., 7 plates.

Clark, D.L., Kirby, S.M., Oviatt, C.G., 2012, Interim geologic map of the Rush Valley 30' x 60' quadrangle, Tooele, Utah, and 
Salt Lake Counties, Utah: Utah Geological Survey Open-File Report 593, Plate 1, scale 1:62,500.

Clark, D.L., Kirby, S.M., Oviatt, C.G., 2019, Interim geologic map of the Rush Valley 30' x 60' quadrangle, Tooele, Utah, and Salt Lake Counties, Utah: National Geologic Map Data Base accessed May 10, 2019, https://ngmdb.usgs.gov/Prodesc/ proddesc 97595.htm, Plate 1, geologic map, scale 1:62,500.

Everitt, B.L., and Kaliser, B.N., 1980, Geology for the assessment of seismic risk in the Tooele and Rush Valleys, Tooele County, Utah: Utah Geological and Mineral Survey Special Study 51, $33 \mathrm{p}$.

Gilluly, J., 1932, Geology and ore deposits of the Stockton and Fairfield quadrangles, Utah: U.S. Geological Survey Professional Paper 173, 171 p., 1 plate, scale 1:62,500.

Handwerger, D.A., Cerling, T.E., and Bruhn, R.L., 1999, Cosmogenic ${ }^{14} \mathrm{C}$ in carbonate rocks: Geomorphology, v. 27, p. 13-24.

Hintze, L.F., 2005, Utah's spectacular geology: Provo, Department of Geology, Brigham Young University, 202 p.

Hintze, L.F., and Kowallis, B.J., 2009, Geologic history of Utah: Provo, Brigham Young University Geology Studies, Special Publication 9, $225 \mathrm{p}$.

Kirby, S.M., 2012, Geologic map of the Ophir quadrangle, Tooele County, Utah: Utah Geological Survey Map 257DM, p. 1-13, 2 plates, scale 1:24,000.

Krahulec, K.A., 2018, Utah mining districts, Utah: Utah Geological Survey Open-File Report 695, 191 p., 1 plate, scale $1: 1,000,000$.

Laes, D.Y.M., Krahulec, K.A., and Ballantyne, G.H., compilers, 1997, Geologic map of the Oquirrh Mountains, Utah, in John, D.A., and Ballantyne, G.H., editors, Geology and ore deposits of the Oquirrh and Wasatch Mountains, Utah: Society of Economic Geologists Guidebook Series, v. 29, 1 plate, scale $1: 62,500$.
Parry, W.T., 2004, All veins, lodes, and ledges throughout their entire depth - geology and the Apex law in Utah mines: Salt Lake City, University of Utah Press, 139 p.

Parry, W.T., 2016, Geology of Utah's mountains, peaks, and plateaus: Victoria, British Columbia, Friesen Press, 244 p.

Stokes, W.L., 1986, Geology of Utah: Salt Lake City, Utah Museum of Natural History, Utah Geological and Mineral Survey, Occasional Paper Utah Museum of Natural History no. 6, 280 p.

Thelin, G.P., and Pike, R.J., 1991, Landforms of the conterminous United States - a digital shaded-relief portrayal: U.S. Geological Survey Map I-2206, https://pubs.usgs.gov/imap/i2206/, accessed January 2019.

Tooker, E.W., and Roberts, R.J., 1998, Geologic map of the Oquirrh Mountains and adjoining south and western Traverse Mountains, Tooele, Salt Lake and Utah counties, Utah: U.S. Geological Survey Open-File Map 98-581, 2 plates, scale 1:50,000.

U.S. Bureau of Land Management, 1993, State of Utah shaded relief map: Library of Congress www.loc.gov/item/95682023/ accessed January 2019.

U.S. Geological Survey, 2019, National Map: https://viewer. nationalmap.gov/advanced-viewer/ accessed January and February 2019. 